\title{
Single-cross performance in off-season in function of urea sources on side-dressing fertilization
}

Gabriel Wiest ${ }^{1}$

Cassiano Spaziani Pereira²

Ivan Vilela Andrade Fiorini ${ }^{3}$

Mateus Emanuel Schoffen ${ }^{4}$

Helcio Duarte Pereira 5

Adriano Alves da Silva ${ }^{6}$

\section{Abstract}

Nitrogen is the most required element by the maize crop and suffers the greatest losses due to its inappropriate management, mainly when the urea is used as a source of nitrogen. The objective of this work was to evaluate the efficiency of urea sources, with or without urease inhibitor, in sidedress fertilization of commercial single-cross in off-season in Sinop/MT. The experimental design was completely randomized blocks, in factorial scheme $3 \times 5$, with 3 replications. The first factor was three side-dress fertilization: witness (without fertilizer); fertilization with $250 \mathrm{~kg} \mathrm{ha}^{-1}$ of urea and fertilization with $250 \mathrm{~kg} \mathrm{ha}^{-1}$ of urea in the presence of urease inhibitor (UREMAX ${ }^{\circledR}$ ) NBPT. The second factor was five single-crosses: 2B433, DKB255, DKB335, NS45, and SYN522. Vegetative development and yield characteristics were evaluated. The Nitrogen sources did not affect the plant height, stem diameter, and foliar area index, only the chlorophyll content in the leaves. For the yield components, there is an effect of fertilization on the number of grain rows and grain yield. The singlecrosses differ among them in vegetative development and yield characteristics. The Nitrogen in sidedress, in the conditions of this study, using the urea with urease inhibitor, increased the fertilization efficiency and raised the grain yield. The single-crosses DKB 255, 2B433, and SYN 522, with the treatment based on UREMAX ${ }^{\circledR}$, reached the highest yield.

Keywords: Zea mays L. Chlorophyll. Foliar area. Volatilization. Yield components.

\section{Introduction}

The off-season maize in Mato Grosso state is of most importance for the grain production of the country. In the 2018/2019 crop season, the production reached 29,767 thousand tons of maize in

1 Universidade Federal do Mato Grosso (UFMT), Campus Sinop, ICAA-Instituto de Ciências Agrárias e Ambiental, Engenheiro Agrônomo. gabrielwiest@yahoo.com.br. Av. Alexandre Ferronato n 1200, Distrito Industrial. Sinop -MT

2 Universidade Federal do Mato Grosso (UFMT), Campus Sinop, ICAA-Instituto de Ciências Agrárias e Ambiental. Professor associado. caspaziani@yahoo.com.br.

3 Universidade Federal do Mato Grosso (UFMT), Campus Sinop, ICAA-Instituto de Ciências Agrárias e Ambiental, Pós doutor. ivanvaf@yahoo.com.br

4 Universidade Federal do Mato Grosso (UFMT), Campus Sinop, ICAA-Instituto de Ciências Agrárias e Ambiental, Engenheiro Agrônomo. Mateusschoffen2@hotmail.com

5 Universidade Federal do Mato Grosso (UFMT), Campus Sinop, ICAA-Instituto de Ciências Agrárias e Ambiental, Doutorado em Genética pela UFV. hhelciopassos@yahoo.com.br.

6 Centro Universitário de Formiga (UNIFOR), Formiga - MG. Professor efetivo. adrianoas@msn.com. 
the state, representing around $50 \%$ of the total maize off-season production in the country. In the $2019 / 2020$ crop season, the participation of Mato Grosso state in the total maize production had a big increase, estimated at 31,144.5 thousand tons, an increase of $8 \%$ in the cultivated area and $18.2 \%$ on yield, favored by the regular rainy season, which enabled a larger window at sowing and a full plant development (CONAB, 2019).

The sowing season of the maize in off-season crop occur between January and March, being dependent on the previous crop planning. Because maize is a C4 species, it is more efficient on the carbohydrates production, which will be used in the grain production. However, some factors influence the yield, like the adopted seed, fertilization, soil, climatic factors, pest incidence, and management (BERGAMASCHI; MATZENAUER, 2014).

The soil fertility is a limiting factor for grain yield of maize, and there is a linear relationship between yield and nutrients extraction. The nutrients most required by the maize are Nitrogen $(\mathrm{N})$ and Potassium (K), followed by Calcium (Ca), Magnesium (Mg), and Phosphorus (P) (COELHO; RESENDE, 2008).

The initial phase of development takes place about $20 \%$ to $30 \%$ of the total nutrient extraction, with a gradual evolution until the tasseling stage, which marks the end of absorption for $N, P, K$, and $\mathrm{Mg}$. To reach a response on yield, it is necessary to fertilizer the maize in the first 30 days after germination. Besides being the best time to the plant, at this time, it is easy to operate the machinery between the rows of the crop (RESENDE et al., 2008).

The main nutrient in the maize composition is the $\mathrm{N}$, whose main source is urea. Of all $\mathrm{N}$ absorbed by the maize, about $75 \%$ are translocated to the grain, thus close involved with the grain weight. The lack of nutrients affects the grain number and the ear size (IFA, 2016).

The stable forms of $\mathrm{N}$ in the soil and absorbed by the plants are ammonium $\left(\mathrm{NH}_{4}{ }^{+}\right)$and nitrate $\left(\mathrm{NO}_{3}{ }^{-}\right)$. The urea, when in contact with the urease enzyme, suffer the break of molecules, giving rise to ammonia, a volatile compound, enabling the losses by volatilization, which cause losses of up to $22 \%$ of the total $\mathrm{N}$ applied in the soil in the rice (SCIVITTARO et al., 2010).

In the no-till system, the losses of urea are higher, because in that system there is more urease and the contact of the fertilizer with the soil is lower, reducing the ammonium absorption. To avoid the losses by volatilization, alternatives have been sought, among them the application of protected urea with polymers, other $\mathrm{N}$ sources, as ammonium sulfate, and urea with urease inhibitor (NBPT). These fertilizers can be used in the mixture of formulated, establishing at the end of the process the composition of "urea + ammonium sulfate + protected urea", originating an adequate amount of $\mathrm{N}$, with different times of release of $\mathrm{N}$, reducing the losses (TASCA et al., 2011).

The objective of this work was to evaluate the efficiency of urea sources, with or without urease inhibitor, in side-dress fertilization of commercial single-cross in off-season in Sinop/MT.

\section{Material and methods}

The experiment was carried out from February 2019 to June 2019, in a commercial area with coordinates ( $11^{\circ} 37^{\prime} 38^{\prime \prime}$ S and 55'26'38" W) near the BR-163, in the region known as "Mercedes", Sinop/MT city. The local altitude is 380 meters and the climate of the region, by Koppen classification, is the type Am, with an average annual rainfall of $2,000 \mathrm{~mm}$ and average annual temperature of $25^{\circ} \mathrm{C}$, and two well defined seasons, being the rainy one between October and April and the dry one between May and September (SOUZA et al., 2013). 
Before preparing the area and sowing, a soil sampling was performed in the depth of 0-20 $\mathrm{cm}$, collecting five samples, which gave rise to a composite sample. After collecting the samples, they were sent to a lab for chemical and physical analysis and it was obtained the following results: $\mathrm{pH}\left(\mathrm{H}_{2} \mathrm{O}\right)$ : 5.8; $\mathrm{pH}\left(\mathrm{CaCl}_{2}\right): 5.1 ; \mathrm{P}: 32.82 \mathrm{mg} \mathrm{dm}^{3} ; \mathrm{K}: 68 \mathrm{mg} \mathrm{dm}^{3} ; \mathrm{K}: 0.07 \mathrm{cmol} \mathrm{dm}^{3} ; \mathrm{Ca}: 4.10 \mathrm{cmol} \mathrm{dm}^{3}$; Mg: $0.6 \mathrm{cmol} \mathrm{dm} 3$; Al: $0 \mathrm{cmol} \mathrm{dm}{ }^{3} ; \mathrm{H}: 4.13 \mathrm{cmol} \mathrm{dm}^{3} ; \mathrm{H}+\mathrm{Al}: 4.13 \mathrm{cmol} \mathrm{dm}^{3}$; M.O.: $21.74 \mathrm{~g} \mathrm{dm}^{3}$; Sum of Basis: $4.77 \mathrm{cmol} \mathrm{dm}^{3}$; CTC a pH 7.0: $8.9 \mathrm{cmol} \mathrm{dm}^{3}$; V\%: 53.63; Ca Mg: 6.87; Ca K: 58.63; Mg K: 8.53; Ca+Mg/K: 67.16; Sand: $729 \mathrm{~g} \mathrm{dm}^{3}$; Silt: $32 \mathrm{gm} \mathrm{dm}^{3}$; Clay: $239 \mathrm{gm} \mathrm{dm}^{3}$. Based on those results, the soil presents medium texture, high levels of $\mathrm{P}$, and adequate levels of $\mathrm{K}, \mathrm{Ca}$, and $\mathrm{Mg}$ (SOUSA; LOBATO, 2004). The soil is classified as dystrophic yellow oxisol (SANTOS et al., 2013).

The experimental design was in completely randomized blocks, in factorial scheme $3 \times 5$, with 3 replications, totaling 15 treatments and 45 experimental plots. The first factor, with 3 levels of fertilization on side-dress, was: witness (without fertilizers); application of $250 \mathrm{~kg} \mathrm{ha}^{-1}$ of the formulated 25-00-18, without the urease inhibitor; application of $250 \mathrm{~kg} \mathrm{ha}^{-1}$ of the formulated 25-00-18 with urease inhibitor (NBPT), commercial name of UREMAX ${ }^{\circledR}$. The $K$ fertilization was even in all plots. The second factor was the five maize single-cross, being: 2B433, DKB255, DKB335, NS45, and SYN522.

The plots had five rows five-meter long, totaling $12.5 \mathrm{~m}^{2}$. The useful area of the plot was the four central meters, excluding the $0.5 \mathrm{~m}$ of the ends of three central rows, since the two lateral rows were considered borders, totaling $8 \mathrm{~m}^{2}$ of useful plot.

The experimental area was open for more than ten years and has been going through a succession of soybean/maize since then, in the no-till system, since the farmer does not perform any type of soil movement. The sowing was performed on February 8, 2019, sowing a final plant population to obtain 60,000 plants ha-1 with $0.5 \mathrm{~m}$ between rows. In the sowing, $200 \mathrm{~kg} \mathrm{ha}^{-1}$ of the formulated 20-00-20 were applied, corresponding to $40 \mathrm{~kg}$ of $\mathrm{N}$ and $40 \mathrm{~kg}$ of $\mathrm{K}_{2} \mathrm{O}$. The side-dress application was conducted using the formulated 25-00-18, composed of $282 \mathrm{~kg}$ of ammonium sulfate, $418 \mathrm{~kg}$ of urea, and $300 \mathrm{~kg}$ of $\mathrm{K}$, totaling $1,000 \mathrm{~kg}$ of the formulated, and the formulated $25-00-18 \mathrm{MAIZ}{ }^{\circledR}$ composed of $278 \mathrm{~kg}$ of ammonium sulfate, $420 \mathrm{~kg}$ of urea, $300 \mathrm{~kg}$ of $\mathrm{K}$ and $2 \mathrm{~kg}$ of UREMAX. The fertilization with $\mathrm{K}$ was corrected in all treatments with $\mathrm{KCl}$. All side-dress fertilization was applied at the vegetative stage V4 (RITCHIE; HANWAY; BENSON, 2003).

On the sowing day, glyphosate application was carried out, using the commercial product Roundup WG at the dose of $1.5 \mathrm{~kg} \mathrm{ha}^{-1}$ and a fungicide application based on epoxiconazole $160 \mathrm{~g} \mathrm{~L}^{-1}$ and pyraclostrobin $260 \mathrm{~g} \mathrm{~L}^{-1}$, at the dose of $0.25 \mathrm{~L} \mathrm{ha}^{-1}$.

The meteorological data of the rainfall, average temperature, maximum and minimum temperature were obtained through the UFMT station of Sinop, in the period between February 8, 2019 and June 7, 2019, the time which the single-crosses remained in the field (FIGURE 1).

The first evaluations conducted in the experiment took place at the beginning of the reproductive period, at the R2 stage (RITCHIE; HANWAY; BENSON, 2003), on April 1 $1^{\text {st }}, 2019$, in six plants of the useful plot. It was determined the plant height $(\mathrm{PH})$ in meters with the aid of a graduated measuring tape, obtaining the measures from the plant neck, near the soil, until the flag leaf. The stem diameter (SD) was obtained with the aid of a pachymeter measuring the diameter in millimeters at $5 \mathrm{~cm}$ above the soil level. For obtaining the foliar area index (FAI) in meter square, four plants per plot were collected, as close to the ground as possible. After the removal, the plants were taken to the UFMT nursery and, with the aid of a foliar area integrator LICOR ${ }^{\circledR}$ model LI-3010, it was determined the foliar area index. To evaluate the chlorophyll index on the leaves (CLO), the values were collected 
with the aid of a manual chlorophyll meter, ClorofiLOG ${ }^{\circledR}$ (model CFL-1030) by the company Falker. This tool estimates the chlorophyll level by indirect way, by reading the Soil Plant Analysis Development (SPAD) units, taking the data from the below and opposite leaf of the first ear. The SPAD readings obtained by the chlorophyll meter points proportional values of chlorophyll at the leaves are calculated based on the quantity of light transmitted and absorbed through the leaf in two wave lengths with different chlorophyll absorbances (ARGENTA et al., 2001).

Figure 1 - Data of temperature and rainfall during the period of February 8, 2019 until June 7, 2019. Data obtained from the UFMT meteorological station of Sinop/MT.

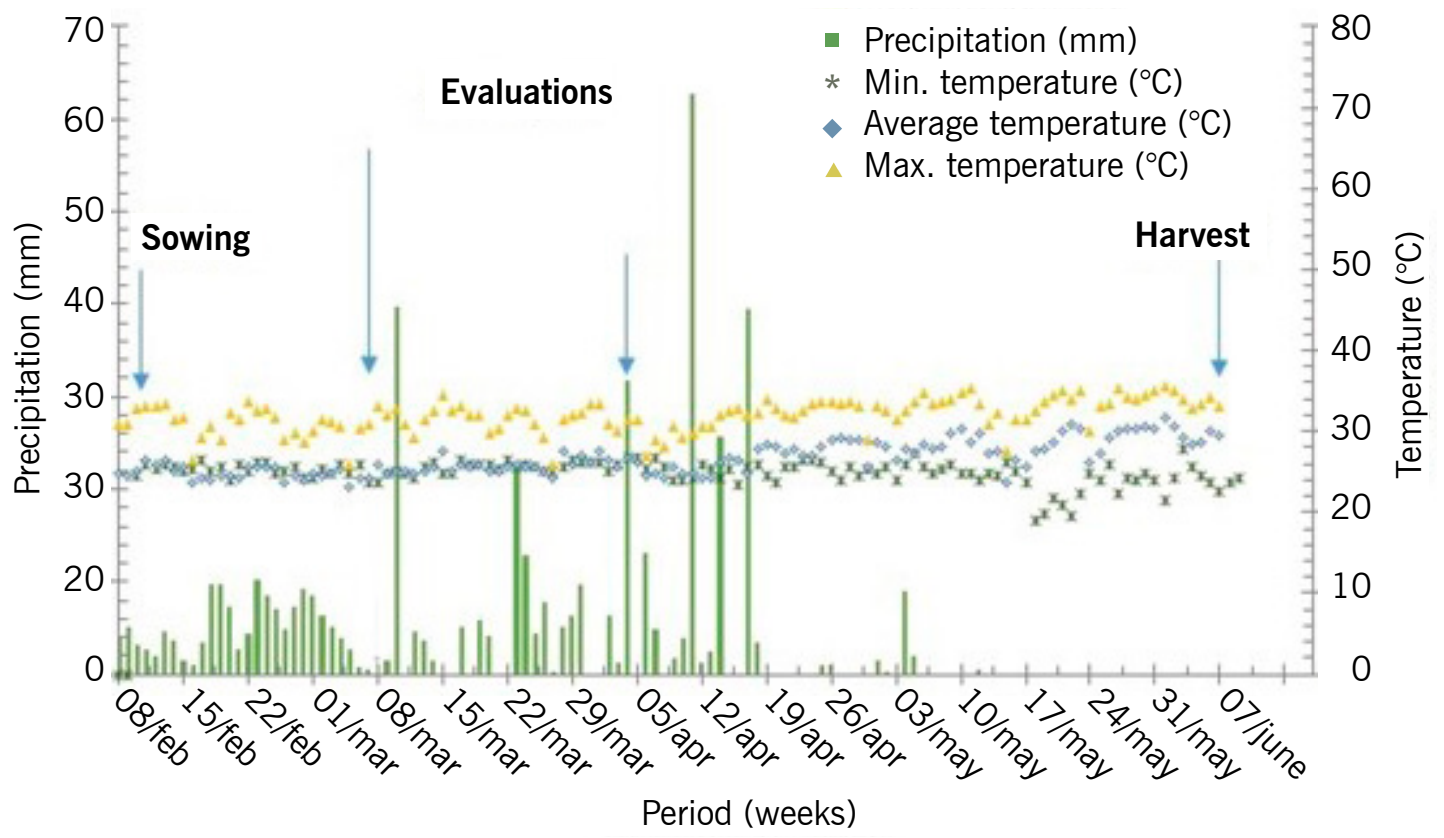

Source: Elaborated by authors (2019).

The harvest was carried out by hand, on June 7, 2019, when the grains had approximately $160 \mathrm{~g} \mathrm{~kg}^{-1}$ of moisture and the ears were at the R6 reproductive stage (RITCHIE; HANWAY; BENSON, 2003). As morphological character for harvesting, we observed the dark layer at the base of the grains. The grains threshing took place on a manual corn thresher Bottini ${ }^{\circledR}$ brand. After threshing, to standardize the yield determination, the grains had the moisture corrected to $130 \mathrm{~g} \mathrm{~kg}^{-1}$ of water and the initial grain moisture was determined by a direct method, in an air-forced greenhouse, at $105{ }^{\circ} \mathrm{C}$, for 24 hours. Next, with all the ears grains, the grain yield was determined in kg plot $^{-1}$ in Filizolla ${ }^{\circledR}$ scale brand, and then converted to $\mathrm{kg} \mathrm{ha}^{-1}$. For the yield components evaluated in this work, it was used 6 ears from each plot, before the threshing, from which we evaluated the number of grain rows (NR) and the number of grain per row (NG), by counting. After the plots were threshed with the aid of a manual corn thresher with subsequent counting and determination of thousandgrain weight (M1000).

The data obtained were submitted to variance analysis at the level of $5 \%$ probability by the $F$ test, with the aid of SISVAR software (FERREIRA, 2011). After the F test ( $p>0.05$ ) from variance analysis, the means were compared by the Scott Knott test (SCOTT; KNOTT, 1974). 


\section{Results and discussion}

The rainfall occurred in 120 days in which the crop remained on the field was $495.8 \mathrm{~mm}$, divided in the months: February: $112.2 \mathrm{~mm}$; March: $170.8 \mathrm{~mm}$; April: $199.6 \mathrm{~mm}$; and May: $13.2 \mathrm{~mm}$, without any rain at the end of May and beginning of June (FIGURE 1). The rainfall and temperatures that occurred during the maize crop cycle favored high yields, without water stress and it was not a limiting factor for yield. According to Ritchie, Hanway, and Benson (2003), at the egg number definition and ear size (V12), the water and nutrient deficiency can seriously decrease the potential number of seeds and ear size, hence the grain yield. To Albuquerque and Resende (2010), medium cycle single-cross, with the objective of grain production, requires from $380 \mathrm{~mm}$ to $550 \mathrm{~mm}$ of water.

The maize growth and development characteristics, as plant height, foliar area, stem diameter, and chlorophyll, differed among the single-crosses (TABLE 1).

Table 1 - Means of the variables plant height $(\mathrm{PH})$ in meters, total Falker chlorophyll index (CLO), stem diameter $(\mathrm{SD})$ in millimeters, and foliar area index (FAI) in meter square from the single-crosses.

\begin{tabular}{ccccc}
\hline \multirow{2}{*}{ Single-cross } & \multicolumn{4}{c}{ Variables analyzed } \\
\cline { 2 - 5 } & PH $(\mathrm{m})$ & CLO (Falker $\left.{ }^{\circledR}\right)$ & SD $(\mathbf{m m})$ & FAI $\left(\mathbf{m}^{2}\right)$ \\
\hline Syn 522 & $1.76 \mathrm{~b}$ & $55.52 \mathrm{a}$ & $21.26 \mathrm{a}$ & $0.9610 \mathrm{a}$ \\
NS45 & $1.97 \mathrm{a}$ & $54.64 \mathrm{a}$ & $22.08 \mathrm{a}$ & $1.1200 \mathrm{a}$ \\
2B433 & $1.90 \mathrm{a}$ & $53.76 \mathrm{a}$ & $21.53 \mathrm{a}$ & $0.9981 \mathrm{a}$ \\
\hline DKB 255 & $1.99 \mathrm{a}$ & $52.58 \mathrm{a}$ & $20.81 \mathrm{a}$ & $1.0026 \mathrm{a}$ \\
\hline DKB 335 & $1.83 \mathrm{~b}$ & $47.35 \mathrm{~b}$ & $19.44 \mathrm{~b}$ & $0.8395 \mathrm{~b}$ \\
\hline C.V.(\%) & 5.35 & 4.07 & 5.35 & 10.36 \\
\hline
\end{tabular}

* The means followed by the same letter in the columns do not differ among them at the level of $5 \%$ probability by the Scott-Knott test (1974).

Source: Elaborated by authors (2019).

For plant height, the single-cross NS 45, 2B433, and DKB 255 reached the highest values, regardless of the fertilization used. According to Lucas (2016), the plant height is closely linked to grain yield, pointing out that the taller the plant the higher the yield, corroborating the results of NS 45 and DKB 255, which presented the highest plant height and great grain yield.

The chlorophyll level at the tasseling stage obtained in this work varied from 47.35 to 55.22 among the single-crosses, from which the single-cross DKB 335 presented the lower value. The average value of the total chlorophyll index was 53 units SPAD, similar to what was obtained by other authors at the maize R2 stage (Argenta et al., 2001; Amaral Filho et al., 2005; Fiorini et al., 2017). The chlorophyll meter provides a fast and practical measure to check efficiently the $\mathrm{N}$ level on the leaves, being an efficient parameter for inferring about the nutritional status of the crops (ARGENTA et al., 2001).

The stem diameter varied from $19.84 \mathrm{~mm}$ to $22.08 \mathrm{~mm}$, in which the single-cross DKB 335 presented the lowest value. The stem diameter is of most importance for maize because it is where the sugars are stored, and in the reproductive period, they are moved to the reproductive parts of the 
plant, and so to grain filling (Magalhães et al., 2002). The foliar area index varied from $0.8395 \mathrm{~m}^{2}$ to $1.1200 \mathrm{~m}^{2}$, from which the single-cross DKB 335 presented the lowest value.

The characteristics of plant height, stem diameter, and foliar area did not differ when analyzed the sources of fertilizers on side-dress, only the chlorophyll index showed significant differences (TABLE 2). Those results corroborate Civardi et al. (2011) who verified that those factors did not have any effect on the urea application. The provision of $\mathrm{N}$ on side-dress with urea or UREMAX increased the levels of chlorophyll. Rodrigues et al. (2018) also verified differences in treatments with or without urea, confirming the precept that $\mathrm{N}$ application on side-dress is essential, regardless of the source. Still, according to the authors, despite the higher values with urease inhibitor application, there were no significant differences, a result that is different of what was found in this study, in which the chlorophyll levels showed a higher value with UREMAX application.

Table 2 - Means of the variables plant height (PH) in meters, chlorophyll index (CLO), stem diameter (SD) in millimeters, and foliar area index (FAI) in meter square as a function of $\mathrm{N}$ sources on side-dress fertilization.

\begin{tabular}{ccccc}
\hline \multirow{2}{*}{ Sources of N: } & \multicolumn{4}{c}{ Variables analyzed } \\
\cline { 2 - 5 } & PH $(\mathbf{m})$ & CLO (Falker $\left.{ }^{\circledR}\right)$ & SD $(\mathbf{m m})$ & FAI $^{\left(\mathbf{m}^{2}\right)}$ \\
\hline Without N & $1.84 \mathrm{a}$ & $49.54 \mathrm{c}$ & $20.64 \mathrm{a}$ & $0.9319 \mathrm{a}$ \\
Urea & $1.91 \mathrm{a}$ & $53.46 \mathrm{~b}$ & $20.97 \mathrm{a}$ & $10043 \mathrm{a}$ \\
Uremax & $1.92 \mathrm{a}$ & $55.30 \mathrm{a}$ & $21.45 \mathrm{a}$ & $1.0165 \mathrm{a}$ \\
\hline C.V.(\%) & 5.35 & 4.07 & 7.36 & 10.36 \\
\hline
\end{tabular}

* The means followed by the same letter in the columns do not differ among them at the level of $5 \%$ probability by the Scott-Knott test (1974).

Source: Elaborated by authors (2019).

The mean yield components, like the number of grains per row, number of grain rows, thousandgrain weight, and grain yield differed among the single-crosses (TABLE 3).

Table 3 - Means of the variables number of grains per row (NG), number of grain row (NR), thousand-grain weight (M1000), and grain yield (GY) in the maize single-crosses.

\begin{tabular}{ccccc}
\hline \multirow{2}{*}{ Single-cross } & \multicolumn{4}{c}{ Variables analyzed } \\
\cline { 2 - 5 } & NG & NR & M1000 (g) & GY (kg ha $\left.\mathbf{~}^{-1}\right)$ \\
\hline 2B433 & $32.83 \mathrm{c}$ & $16.24 \mathrm{a}$ & $334.65 \mathrm{~b}$ & $7,211.35 \mathrm{~b}$ \\
DKB255 & $29.58 \mathrm{~d}$ & $16.20 \mathrm{a}$ & $363.55 \mathrm{a}$ & $8,583.61 \mathrm{a}$ \\
DKB335 & $32.10 \mathrm{c}$ & $15.44 \mathrm{~b}$ & $325.53 \mathrm{~b}$ & $7,881.79 \mathrm{a}$ \\
NS45 & $36.51 \mathrm{a}$ & $15.24 \mathrm{~b}$ & $332.90 \mathrm{~b}$ & $8,011.31 \mathrm{a}$ \\
SYN522 & $34.28 \mathrm{~b}$ & $15.11 \mathrm{~b}$ & $322.45 \mathrm{~b}$ & $6,843.55 \mathrm{~b}$ \\
\hline
\end{tabular}

* The means followed by the same letter in the columns do not differ among them at the level of $5 \%$ probability by the Scott-Knott test (1974).

Source: Elaborated by authors (2019). 
The number of grains per row varied from 32.83 to 36.51 and the single-cross NS 45 presented the highest value, being that result close related to the greater amount of grains on the ear. The single-crosses DKB 255 and 2B433 reached the highest values of the number of grain rows, leading to understanding that the use of $\mathrm{N}$ in these single-crosses was more efficient. When the $\mathrm{N}$ supply is not enough during the stage of tassel differentiation, it may cause a lower number of eggs at the ear beginnings and reduced number of grains, besides that, a Boron and Calcium deficiency can lead to losses in pollination, because those nutrients are essential in the stigma composition (ERNANI et al., 2005).

For thousand-grain weight, the single-cross DKB 255 was superior with $363.55 \mathrm{~g}$, as well as high grain yield means with $8,583.61 \mathrm{~kg} \mathrm{ha}^{-1}$ (139.99 bags ha-1). Because of that, it is probably that DKB 255 has a larger $N$ extraction and usage of it. Thousand-grain weight is important because it is a direct factor to explain the yield, demonstrating which treatment had the most relevance to fill the grain. After all, around $75 \%$ of the absorbed $\mathrm{N}$ is translocated to the grain (RITCHIE; HANWAY; BENSON, 2003), but this factor is dependent on extraction and exportation to the grain. The grain yields were superior for the single-crosses DKB 255, NS 45, and DKB 335, with means of 8,583.61, $8,011.31$, and 7,881.79, respectively.

Concerning $N$ sources on side-dress, there were differences for the number of grain row and grain yield, in which the source UREMAX was superior to conventional urea and witness with $338 \mathrm{~g}$ and $8,424.35 \mathrm{~kg} \mathrm{ha}^{-1}$, respectively. For the number of grains per row and thousand-grain weight, there were no differences among the $\mathrm{N}$ sources on side-dress (TABLE 4).

Table 4 - Means of the variables number of grains per row (NG), number of grain row (NR), thousand-grains weight (M1000), and maize grain yield (GY).

\begin{tabular}{ccccc}
\hline \multirow{2}{*}{ Sources of N: } & \multicolumn{4}{c}{ Variables analyzed } \\
\cline { 2 - 5 } & NG & NR & M1000 (g) & GY (kg ha $\left.\mathbf{~}^{-1}\right)$ \\
\hline Uremax $^{\circledR}$ & $32.68 \mathrm{a}$ & $16.05 \mathrm{a}$ & $338.82 \mathrm{a}$ & $8,424.35 \mathrm{a}$ \\
Urea & $33.58 \mathrm{a}$ & $15.58 \mathrm{~b}$ & $337.59 \mathrm{a}$ & $7,703.55 \mathrm{~b}$ \\
Without N & $32.92 \mathrm{a}$ & $15.30 \mathrm{~b}$ & $331.05 \mathrm{a}$ & $6,991.07 \mathrm{c}$ \\
\hline C.V.(\%) & 5.60 & 4.42 & 4.62 & 11.68 \\
\hline
\end{tabular}

* The means followed by the same letter in the columns do not differ among them at the level of $5 \%$ probability by the Scott-Knott test (1974).

Source: Elaborated by authors (2019).

According to Sousa et al. (2017), the application of coated urea provides an increase in the number of grain rows of about $1.9 \%$ regarding conventional urea, data that corroborate the results presented here. This character is defined on the V8 stage, evidencing a possible decrease in $\mathrm{N}$ loss and making available this element, resulting in a larger number of rows (CARMO et al., 2012). The number of rows is defined on the V8 stage (RITCHIE; HANWAY; BENSON, 2003), therefore, it needs a proper $\mathrm{N}$ supply like the one in this experiment, since side-dress fertilization was carried out in that time. Some single-crosses needs larger $\mathrm{N}$ levels to respond, justifying the difference between them (FORNASIERE FILHO, 2007).

Kappes and Silva (2016) obtained average increases of $7.6 \%$ on grain yield with the $\mathrm{N}$ application, compared to the witness without $\mathrm{N}$ on side-dress, regardless the urea source used. 
Kappes et al. (2009) observed significant increases in grain yield with the application of $70 \mathrm{~kg} \mathrm{ha}^{-1}$ of $\mathrm{N}$, regardless of the source used.

Rodrigues et al. (2018) verified that urea supply is beneficial to the maize even in years of favorable climatic conditions, obtaining gains of $31 \%$ on the yield on the treatment with urea and urease inhibitor, Super $N \circledast$. As well as the climatic conditions mentioned before favored the maize development in this study, it is also clear the high yield of the witness treatment, for which it should be noted that $40 \mathrm{~kg} \mathrm{ha}^{-1}$ of $\mathrm{N}$ was applied at sowing, but no side-dress fertilization was carried out, still its yield is in the same average values of the ones with $\mathrm{N}$ application on sidedress (RESENDE et al., 2018).

Analyzing the unfolding interaction, we verify that the single-crosses responded differently to the urease inhibitor usage, but they all presented gains on yield in comparison to the witness treatment. The urea provided similar values to the urea with inhibitor at the single-crosses NS 45 and DKB 335. Mota et al. (2015) stated that different urea sources did not have any effect on yield, but the two single-crosses cited had a great final yield, demonstrating highly responsive to side-dress fertilization, independently of the source.

Frazão et al. (2014) found that usage of urea treated with the addition of NBPT reached an increase of 13 bags ha-1 when compared to common urea and an increase of 23 bags ha-1 regarding the witness, demonstrating a possible decrease in $\mathrm{N}$ loss by volatilization, hence, higher levels of $\mathrm{N}$ available to the plants. In the present work, the single-cross DKB 255 reached the highest values

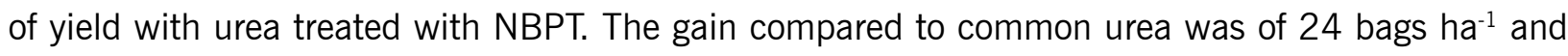
37 bags ha-1 $^{-1}$ regarding the witness (FIGURE 2).

Figure 2 - Means of single-crosses for the variable grain yield in bags ha-1 as a function of sources of $\mathrm{N}$. Inside every single-cross, the sources followed by the same letter do not differ among them at $5 \%$ probability by the Scott-Knott test (1974).

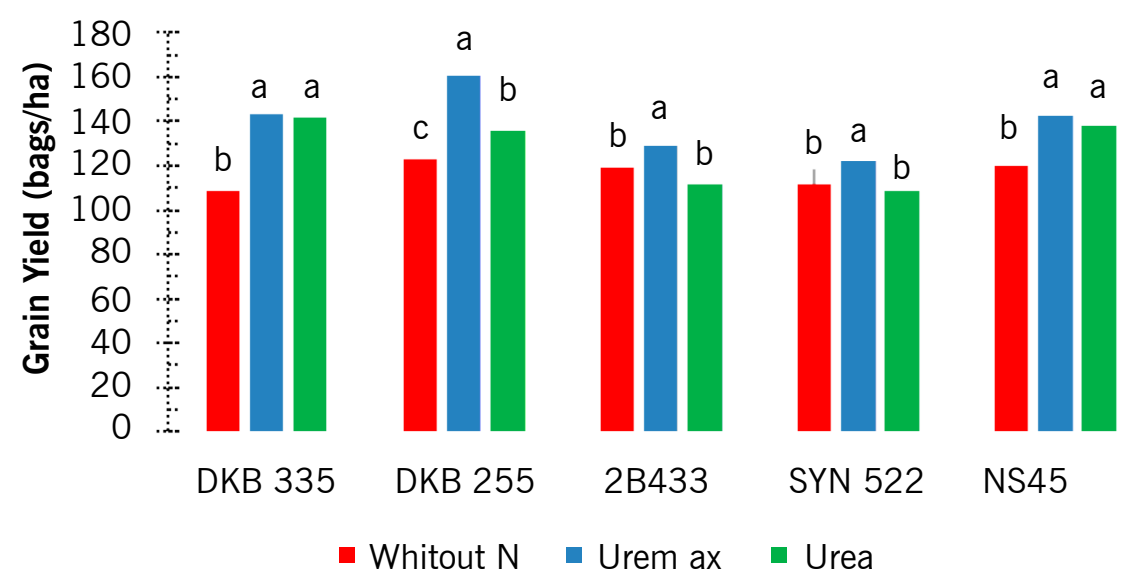

Source: Elaborated by authors (2019).

The most outstanding single-cross was the DKB 255 which reached 160 bags ha-1 $\left.^{-1} 9,600 \mathrm{~kg} \mathrm{ha}^{-1}\right)$ with the usage of urea and UREMAX on side-dress, about $31 \%$ higher than the witness and with gains of $18 \%$ compared to common urea (FIGURE 2). That difference in yield can be explained by the probable decrease on urea volatilization rates, according to Guelfi (2017), who verified a reduction of $79 \%$ in urea volatilization when treated with a urease inhibitor. It should be noted that 
two days after the side-dress fertilization, which happened on March 8, 2019, there was a rainfall of $40 \mathrm{~mm}$, facilitating the fertilizers incorporation into the soil and reducing their losses.

\section{Conclusions}

The $\mathrm{N}$ supply on side-dress fertilization in the conditions of this work, using as source urea with urease inhibitor, increased the fertilization efficiency and raised the grain yield in 2019.

The single-crosses DKB 255, 2B433, and SYN 522, with the UREMAX treatment, reached the best results when compared to only urea usage. The single-cross DKB 255 stood out, reaching the highest average grain yield.

\section{Desempenho de híbridos de milho safrinha em função de fontes de ureia na adubação de cobertura}

\section{Resumo}

O nitrogênio é o elemento mais demandado pela cultura do milho e também o que sofre as maiores perdas devido a seu manejo inadequado, principalmente quando se utiliza a ureia como fonte do elemento. Objetivou-se com este trabalho avaliar a eficiência de fontes de ureia, com ou sem inibidor de urease, na adubação de cobertura de híbridos comerciais em milho safrinha em Sinop/MT. 0 delineamento experimental foi em blocos ao acaso, em esquema fatorial $3 \times 5$, com três repetições. 0 primeiro fator consistiu em três adubações de cobertura: testemunha (sem aplicação de adubo); adubação com $250 \mathrm{~kg} \mathrm{ha}^{-1}$ de ureia e adubação com $250 \mathrm{~kg} \mathrm{ha}^{-1}$ de ureia com a presença do inibidor de urease (UREMAX ${ }^{\circledR}$ ) NBPT. O segundo fator foram cinco híbridos de milho: 2B433, DKB255, DKB335, NS45 e o SYN522. Avaliaram-se características de desenvolvimento vegetativo e de produtividade. As fontes de nitrogênio não afetam a altura de plantas, diâmetro de colmo e índice de área foliar, apenas o teor de clorofila nas folhas. Para os componentes de produtividade, há efeitos das adubações no número de fileiras de grãos e na produtividade. Os híbridos diferem entre si nas características de desenvolvimento vegetativo e de produtividade. A aplicação em cobertura de nitrogênio, nas condições do estudo e utilizando como fonte ureia com inibidor de urease, aumentou a eficiência da adubação e elevou a produtividade nos híbridos de milho. Os híbridos DKB 255, 2 B433 e SYN 522, com o tratamento com UREMAX ${ }^{\circledR}$, atingiram as maiores produtividades.

Palavras-chave: Zea mays L. Clorofila. Área foliar. Volatilzação. Componentes de produtividade

\section{References}

ALBUQUERQUE, P. E. P.; RESENDE, M. Cultivo do milho: manejo de irrigação. 2010. Disponível em: https://goo.gl/tn2uNQ. Acesso em: 15 jun. 2019.

AMARAL FILHO, J. P. R.; FORNASIERI FILHO, D.; FARINELLI, R.; BARBOSA, J. C. Espaçamento, densidade populacional e adubação nitrogenada na cultura do milho. Revista Brasileira Ciência do Solo, v. 29, n. 1, p. 467-473, 2005. 
ARGENTA, G.; SILVA, P. R. F.; BORTOLINI, C. G.; FORSTHOFER, E. L.; STRIEDER, M. L. Relação da leitura do clorofilômetro com os teores de clorofila extraível e de nitrogênio na folha de milho. Revista Brasileira Fisiologia Vegetal, v. 13, n. 2, p. 158-167, 2001.

BERGAMASCHI, H.; MATZENAUER, R. 0 milho e o clima. Porto Alegre: Emater/RS-Ascar, p. 11, 2014.

CARMO, M. S.; CRUZ, S. C. S.; SOUZA, E. J. de; CAMPOS, L. F. C.; MACHADO, C. G. Doses e fontes de nitrogênio no desenvolvimento e produtividade da cultura de milho doce. Bioscience Journal, v. 28, p. 223-231, 2012.

CIVARDI, E. A.; SILVEIRA NETO, A. N. D.; RAGAGNIN, V. A.; GODOY, E. R.; BROD, E. Uréia de liberação lenta aplicada superficialmente e ureia comum incorporada ao solo no rendimento do milho. Pesquisa Agropecuária Tropical, v. 41, n. 1, p. 52-59, 2011.

COELHO, A. M.; RESENDE, Á. V. Exigências nutricionais e adubação do milho safrinha. Sete Lagoas: Embrapa Milho e Sorgo, 2008.

COMPANHIA NACIONAL DE ABASTECIMENTO (CONAB). Acompanhamento da safra brasileira de grãos: Oitavo levantamento. 8 ed. Brasília, 2019.

ERNANI, P. R.; SANGOI, L.; LECH, V. A.; RAMPAZZO, C. A forma de aplicação da uréia e dos resíduos vegetais afeta a disponibilidade de nitrogênio. Ciência Rural, v. 35, n. 2, p. 360-365, 2005.

FERREIRA, D. F. Sisvar: A computer statistical analysis system. Ciência e Agrotecnologia, Lavras, v. 35, n. 6, p. 1039-1042, 2011. Disponível em: http://www.scielo.br/pdf/cagro/v35n6/a01v35n6. pdf. Acesso em: 18 jul. 2019.

FIORINI; I. V. A.; VON PINHO, R. G.; PEREIRA, H. D.; PIRES, L. P. M.; FIORINI, F. V. A. E RESENDE, E. L. Dry matter accumulation, chlorophyll and sulfur leaf in corn fertilized with different sulfur sources. Journal Bioenergy and Food Science, v. 4, n. 1, p. 1-11, 2017.

FORNASIERI FILHO, D. Manual da cultura do milho. Jaboticabal: Funep, 2007. 576 p.

FRAZÃO, J. J.; SILVA, Á. R. D.; SILVA, V. L. D.; OLIVEIRA, V. A.; CORRÊA, R. S. Fertilizantes nitrogenados de eficiência aumentada e ureia na cultura do milho. Revista Brasileira de Engenharia Agrícola e Ambiental, v. 18, n. 12, p. 1262-1267, 2014.

GUELFI, D. Fertilizantes nitrogenados estabilizados, de liberação lenta ou controlada. Informações agronômicas IPNI, v. 157, n. 19, p. 1-32, 2017.

IFA - International Fertilizer Industry Association. Nutrient Management Handbook, 2016. Disponível em: http://www.fertilizer.org/. Acesso em: 20 maio 2019.

KAPPES, C.; CARVALHO, M. A. C. de; YAMASHITA, O. M.; SILVA, J. A. N. da. Influência do nitrogênio no desempenho produtivo do milho cultivado na segunda safra em sucessão à soja. Pesquisa Agropecuária Tropical, v. 39, n. 3, p. 251-259, 2009. 
KAPPES, C.; SILVA, R. G. Fontes e doses de nitrogênio no cultivo do milho safrinha em sucessão à soja. Enciclopédia Biosfera, v. 13, n. 23, p. 646-659, 2016.

LUCAS, F. T. Efeitos da ureia com inibidores de nitrificação e urease na cultura do milho. 2016. $60 \mathrm{f}$. Tese (Doutor em Agronomia - Produção Vegetal) - Faculdade de Ciências Agrárias e Veterinárias. Universidade Estadual Paulista - UNESP Campus de Jaboticabal, 2016.

MAGALHAES, P. C.; DURAES, F. O.; CARNEIRO, N. P.; PAIVA, E. Fisiologia do milho. Sete Lagoas: EMBRAPA-CNPMS, Circular Técnica, 22. 23 p. 2002.

MOTA, M. R.; SANGOI, L.; SCHENATTO, D. E.; GIORDANI, W.; BONIATTI, C. M.; DALL'IGNA, L. Fontes estabilizadas de nitrogênio como alternativa para aumentar o rendimento de grãos e a eficiência de uso do nitrogênio pelo milho. Revista Brasileira de Ciencia do Solo, v. 39, n. 2, p. 512-522, 2015.

RESENDE, A. V.; BORGHI, E.; GONTIJO NETO, M. M.; ABREU, S. C.; SANTOS, F. C. dos; COELHO, A. M. Manejo de nutrientes no cultivo de milho segunda safra na região do cerrado. Revista Plantio Direto, v. 166, 2018.

RITCHIE, S. W.; HANWAY, J. J.; BENSON, G. O. Como a planta de milho se desenvolve. Informações agronômicas, v. 103, p. 1-19, 2003.

RODRIGUES, F. J.; BARCAROL, M. A.; ADAMS, C. R.; KLEIN, C.; BERWANGER, A. L. Eficiência agronômica da cultura do milho sob diferentes fontes de nitrogênio em cobertura. Uniciências, v. 22, n. 2 , p. $66,2018$.

SANTOS, H. G.; JACOMINE, P. K. T.; ANJOS, L. H. C. dos; OLIVEIRA V. A. de; LUMBRERAS, J. F.; COELHO, M. R.; ALMEIDA, J. A. de; CUNHA, T. J. F.; OLIVEIRA, J. B. de. Sistema brasileiro de classificação dos solos. 3 ed. Brasília, DF: Embrapa, 2013. 353 p.

SCIVITTARO, B. W.; GONÇALVES, D. R. N.; VALE, M. L. C do; RICORDI, V. G. Perdas de nitrogênio por volatilização de amônia e resposta do arroz irrigado à aplicação de ureia tratada com o inibidor de urease NBPT. Ciência Rural, Santa Maria, v. 40, n. 6, p. 1283-1289, jun., 2010.

SCOTT, A. J.; KNOTT, M. A cluster analysis method for grouping means in the analysis of variance. Biometrics, p. 507-512, 1974.

SOUSA, D. M. G.; LOBATO, E., eds. Cerrado: Correção do solo e adubação. Planaltina, Embrapa Cerrados, 2004.

SOUZA, A. P.; MOTA, L. L.; ZAMADEI, T.; MARTIN, C. C.; ALMEIDA, F. T., PAULINO, J. Classificação climática e balanço hídrico climatológico no estado de Mato Grosso. Nativa, v. 1, p. 34-43, 2013.

SOUZA, D. S.; LIMA, S. F.; CADORE, E.; DAVID, C. H. O.; SANTOS, O. F. Aplicação de ureia revestida e produtos foliares no milho safrinha. Nucleus, v. 14, n. 1, 2017. 
TASCA, F. A.; ERNANI, P. R.; ROGERI, D. A.; GATIBONI, L. C.; CASSOL, P. C. Volatilização de amônia do solo após a aplicação de ureia convencional ou com inibidor de urease. Revista Brasileira de Ciência do Solo, v. 35, n. 2, 2011.

Received: March 16, 2020

Accepted: July 9, 2020 